\title{
First data on the movements of Iberochondrostoma almacai (Coelho, Mesquita \& Collares-Pereira, 2005) out of dry- season pools in a Mediterranean stream
}

Daniel Filipe Pires \& Maria Filomena Magalhães

Centro de Biologia Ambiental, Faculdade de Ciências, Universidade de Lisboa, Campo Grande 1749-016 Lisboa, Portugal.

Correspondence

D.F. Pires

BIOTA - Estudos e Divulgação em

Ambiente, Lda, Praceta de São Carlos, loja

1 A, 1685-597 Caneças, Portugal

E-mail: dpires@biota.pt

Received: 25 May 2013

Accepted: 1 October 2013

Published on-line: 23 October 2013

\section{Resumen}

Primeros datos de los movimientos de Iberochondrostoma almacai (Coelho, Mesquita \& Collares-Pereira, 2005) desde de los refugios de estación seca, en un arroyo temporal mediterráneo

La salida de los refugios durante la estación seca puede ser fundamental para la persistencia de los peces que habitan en arroyos temporales, aunque es un proceso poco conocido. En el presente trabajo, cuantificamos los movimientos desde refugios de Iberochondrostoma almacai en un arroyo mediterráneo mediante técnicas de marcaje-recaptura. Aunque algunos individuos permanecieron sedentarios, también se detectaron ejemplares con movimientos superiores a $200 \mathrm{~m}$ desde los refugios, tanto aguas arriba como aguas abajo y ocupando hábitats más o menos persistentes. Estos resultados sugieren que la especie tiende a redistribuirse tras la recuperacion de los caudales y a colonizar sitios anteriormente secos.

Palabras clave: Ciprinidae; Dispersión de peces; Recolonización de hábitats; Arroyos temporales; Sequía estival.

\begin{abstract}
Movement out of dry-season refugia may be critical to fish persistence in temporary streams, though it remains poorly understood. Here we quantify the movements by the Southwestern archedmouth nase out of dry-season pools in a mediterranean stream, using a mark-recapture design. Although some nase were sedentary, some individuals moving out of dry-season pools displaced more than $200 \mathrm{~m}$, both upstream and downstream, and into persistent and ephemeral sites. This suggests that nase may redistribute after flow resumption and colonize sites that were previously dry.
\end{abstract}

Key words: Cyprinidae, Fish dispersal, Habitat recolonization, Temporary streams, Drought.

\section{Introduction}

Movement underlies many ecological patterns and processes in stream fish including the colonization of unoccupied habitats and recovery of populations after local extinction. Intuitively, this should be particularly important in temporary streams in promoting population persistence in the face of drought. Droughts in temporary streams disrupt hydrological connectivity and reduce habitat to a few, patchy refugia (Larned et al. 2010). Individuals in refugia survive drought, and may provide recruits or colonists for the entire system after flow resumption. Although population persistence may strictly dependent on this, movements of fish out of refugia and its ability to redistribute and 
colonize previously dewatered habitats remain unclear.

This study examines the movements out of dry-season pools by the Southwestern archedmouth nase Iberochondrostoma almacai in a seasonally-drying mediterranean stream. This recently described species is endemic to small drainages in SW Portugal (Coelho et al. 2005) and currently listed as Endangered (Rogado et al. 2005).

\section{Materials and Methods}

Our study was conducted in a $3.6 \mathrm{~km}$ reach in the Torgal stream $\left(37^{\circ} 38^{\prime} \mathrm{N}, 8^{\circ} 39^{\prime} \mathrm{W}\right)$ in September 2007. The Torgal is a small $(28.0 \mathrm{~km})$, relatively undisturbed, and highly seasonal stream, where large floods may occur in winter but large sections of the channel dry up to disconnected pools in summer-early fall (Magalhães et al. 2002). During our study the average nearest-distance between disconnected pools was $98 \mathrm{~m}( \pm 56$; 19-196).

We sampled for fish in 10 wadeable pools, using electrofishing (Hans Grass1 EL62 IIGI, 300 V, 4-6 A, pulsed D.C). We tagged nases with Visual Implant Elastomers (VIE, Northwest Marine Technology INC) and Passive Integrated Transponder tags (PIT, Trovan ID-100A, 2.12x11.5 mm), which are both considered suitable for small fishes (e.g. Pires et al. 2010, Roberts \& Angermeier 2007). VIE were subcutaneously inserted with a needle in the ventral part of and at the base of pectoral fin of fish. PIT tags were inserted into the body cavity through an incision using a sharpened needle. All fish were anaesthetized with clove oil prior to marking and allowed to recover and regain balance and swimming before release.

We conducted four recapture surveys after flow resumption, between December 2007 and June 2008. In each survey, we electrofished 60 stretches, $15 \mathrm{~m}$ long, spread across the study reach at least $20 \mathrm{~m}$ apart. All fish were examined for marks and recaptures measured for fork length.

We classified as movement those instances when a fish was recaptured in a location other than the pool in which it had been marked and assumed that the net displacement distance between the marking and recapture locations represents the total distance the fish had moved. Fish recaptured in their marking pools were thus considered stayers and attributed a movement distance of zero; fish recaptured beyond their marking pools were considered movers and attributed the distance along the stream between the midpoints of mark and recapture, measured in a GIS using 1:25,000 digital cartography (http://www.igeoe.pt).

\section{Results}

We tagged 385 nases (342 VIE, 43 PIT) but only recaptured 11 (9 VIE, 2 PIT). The numbers of nase moving out and remaining in dry-season pools were similar (6 vs. 5; Chi-Square test: $\left.\chi^{2}=0.09, \mathrm{df}=1, p=0.763\right)$. Also, there were no differences in body size between movers and stayers $(74.6 \pm 4.5 \mathrm{~mm}$ vs. $72.2 \pm 5.5 \mathrm{~mm} ; \mathrm{U}=10.0$, $\mathrm{P}=0.411$ ). Nase moved mostly downstream (5 vs. 1) although this variation in directionality was not significant (Chi-Square test: $\chi^{2}=2.67, \quad \mathrm{df}=1$, $p=0.102$ ). Downstream displacements ranged between 236 and $604 \mathrm{~m}$ and were to both persistent and ephemeral sites, whereas the only upstream displacement targeted an ephemeral site at $209 \mathrm{~m}$ from the pool of marking.

\section{Discussion}

We obtained low recapture rates which may be partially related to tag loss, fish mortality and movement to unsampled areas (Roberts \& Angermeier 2007). Nevertheless, our study provides some insight on nase movements out of dry-season pools. Although some nase showed fidelity to dry-season pools, other individuals moved out and displayed long displacements $(>200 \mathrm{~m})$, up and downstream, that surpassed the average nearest-distance between pools. These displacements were similar to those recorded for other small bodied stream fishes (Breen et al. 2009, Pires 2012, Roberts \& Angermeier 2007), and targeted both ephemeral and persistent sites. This suggests that at least some nase sheltering in dry-season pools in mediterranean streams may redistribute and colonize previously dewatered habitats after flow resumption, as found in other temporary streams (Walker et al., 2012). However, further studies are required to fully characterize nase movement patterns and abiotic and biotic factors driving such patterns. Ultimately, clarifying whether variation in mobility may translate into differences in individual fitness and viability will be critical to inform conservation efforts in the 
face of increasing intermittency of riverscapes.

\section{Acknowledgements}

This study was conducted under permits of the Portuguese Forestry Authority (10/2008) and the Institute for Nature Conservation and Biodiversity (316/2007). Funding was provided by the Portuguese Science Foundation (PPCDT/BIABDE/56272/2004), which also supported D.F. Pires (SFRH/BD/21861/2005). We thank Filipe Ribeiro, Joana Martelo and Amy Olivier for their invaluable help in the field.

\section{References}

Breen MJ, Ruetz CR, Thompson, KJ \& Kohler SL. 2009. Movements of mottled sculpins (Cottus bairdii) in a Michigan stream: how restricted are they? Canadian Journal of Fisheries and Aquatic Sciences 66 (1): 31-41.

Coelho MM, Mesquita M \& Collares-Pereira MJ. 2005. Chondrostoma almacai, a new cyprinid species from the southwest of Portugal, Iberian Peninsula. Folia Zoologica 54(1-2):201-212.

Larned ST, Datry T, Arscott DB \& Tockner K. 2010.
Emerging concepts in temporary-river ecology. Freshwater Biology 55 (4): 717-738.

Magalhães MF, Beja P, Canas C \& Collares-Pereira, MJ. 2002. Functional heterogeneity of dry-season fish refugia across a Mediterranean catchment: the role of habitat and predation. Freshwater Biology 47 (10): 1919-1934.

Pires DF, Ribeiro, F \& Magalhães, MF. 2010. Evaluation of PIT-tagging in an endangered Iberian cyprinid. Journal of Applied Ichthyology 26 (4): 612-613.

Pires DF. 2012 Fish distribution and abundance in mediterranean streams: the role of habitat quality, spatial context, and movement patterns. PhD. Thesis. Lisboa: Universidade de Lisboa.

Roberts J \& Angermeier, P. 2007. Spatiotemporal variability of stream habitat and movement of three species of fish. Oecologia 151 (3): 417-430.

Rogado L, Alexandrino PJ, Almeida PR, Alves MJ, Bochechas J, Cortes RV, Domingos MI, Filipe AF, Madeira J \& Magalhães MF. 2005. Boga do Sudoeste Chondrostoma almacai. In Livro Vermelho dos Vertebrados de Portugal (Cabral MJ, Almeida J, Almeida PR, Dellinger T, Ferrand De Almeida N, Oliveira ME, Palmeirim JM, Queiroz AI, Rogado $L$ and Santos-Reis M,eds). Lisboa: Instituto da Conservação da Natureza. pp.83-84.

Walker RH, Adams GL \& Reid Adams S. 2012. Movement patterns of southern redbelly dace, Chrosomus erythrogaster, in a headwater reach of an Ozark stream. Ecology of Freshwater Fish 22 (2): 216-227. 